\title{
A Hydrogeologic Map of the Death Valley Region, Nevada and California, Developed Using GIS Techniques
}

by Claudia C. Faunt, Frank A. D'Agnese, and A. Keith Turner

$$
\text { USGS/WRIR--95-40/6 }
$$

U.S. GEOLOGICAL SURVEY

Water-Resources Investigations Report 95-4016

Prepared in cooperation with the

NEVADA OPERATIONS OFFICE,

U.S. DEPARTMENT OF ENERGY, under

Interagency Agreement DE-Al08-92NV10874

DISTRIBUTION OF THIS DOCUMENT is UNLMMTED

Denver, Colorado

1997

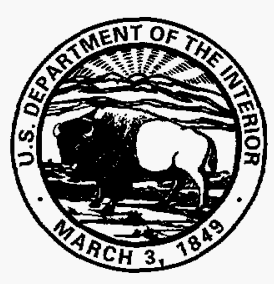




\title{
U.S. DEPARTMENT OF THE INTERIOR \\ BRUCE BABBITT, Secretary
}

\author{
U.S. GEOLOGICAL SURVEY
}

Gordon P. Eaton, Director

The use of firm, trade, and brand names in this report is for identification purposes only and does not constitute endorsement by the U.S. Geological Survey.

For additional information write to:

Chief, Hydrologic Investigations Program

Yucca Mountain Project Branch

U.S. Geological Survey

Box 25046, Mail Stop 421

Denver Federal Center

Denver, CO 80225-0046
Copies of this report can be purchased from:

U.S. Geological Survey

Branch of Information Services

Box 25286

Denver, CO 80225-0286 


\section{DISCLAIMER}

Portions of this document may be illegible electronic image products. Images are produced from the best available original document. 


\section{CONTENTS}

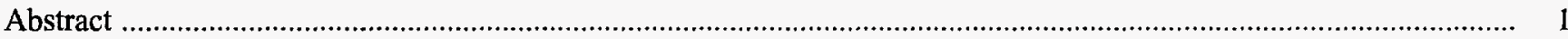

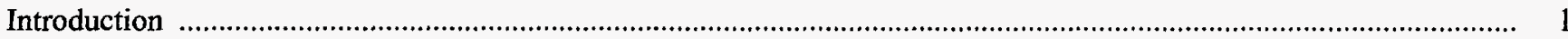

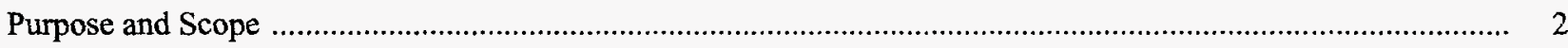

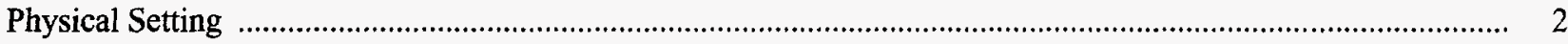

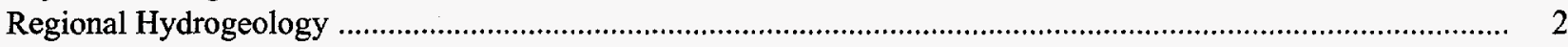

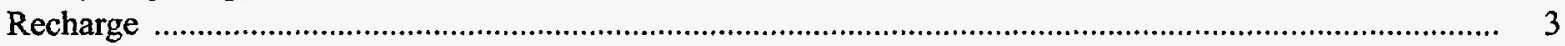

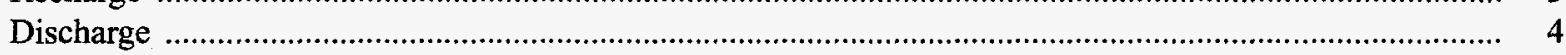

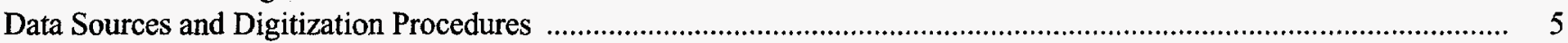

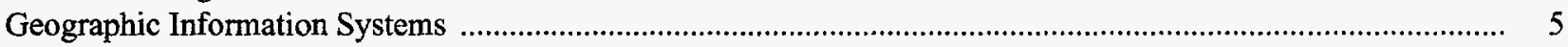

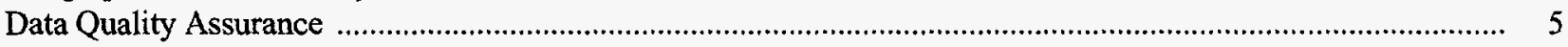

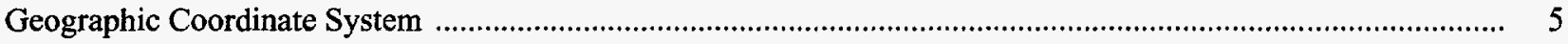

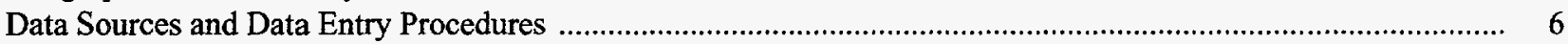

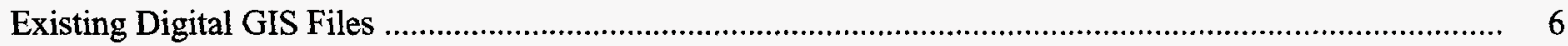

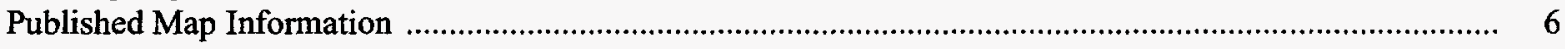

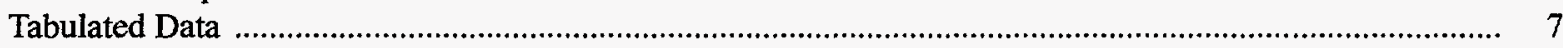

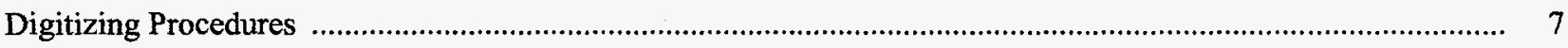

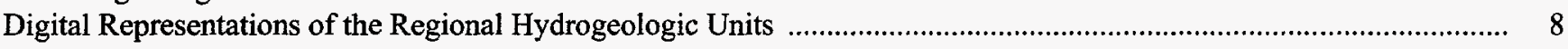

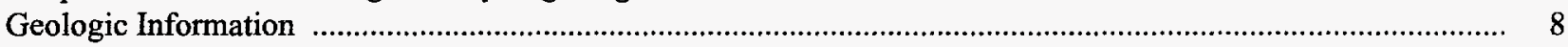

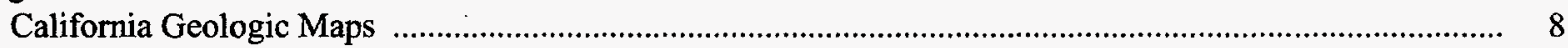

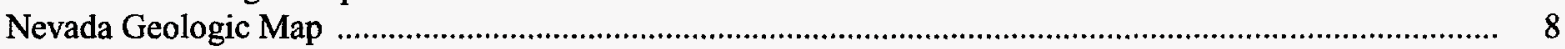

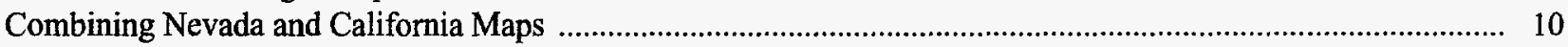

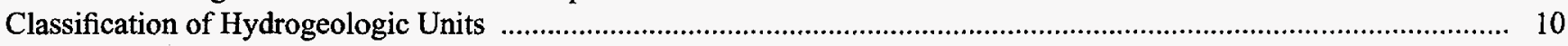

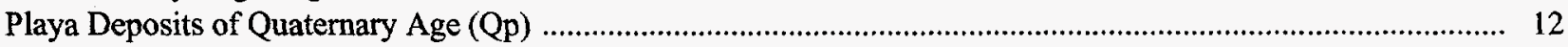

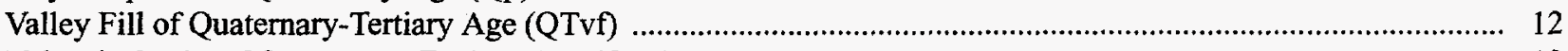

Volcanic Rocks of Quaternary-Tertiary Age (QTv) ................................................................................. 12

Volcanic Rocks of Tertiary Age (Tv) .......................................................................................................... 12

Volcanic and Volcaniclastic Rocks of Tertiary Age (Tvs) ....................................................................................... 13

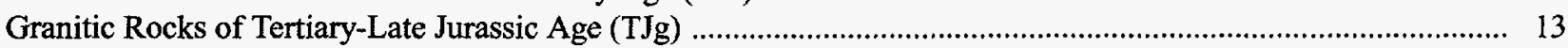

Sedimentary and Metavolcanic Rocks of Mesozoic Age (Mvs) ................................................................. 13

Carbonate Rocks of Paleozoic Age (P2) ............................................................................................. 13

Clastic Rocks of Paleozoic-Precambrian Age (P1) .................................................................................. 13

Igneous and Metamorphic Rocks of Precambrian Age (p€gm) ..................................................................

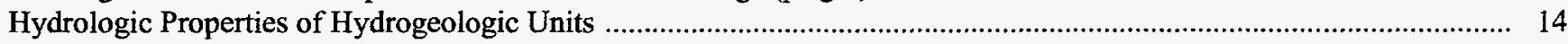

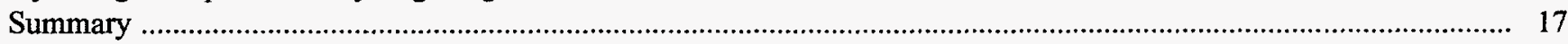

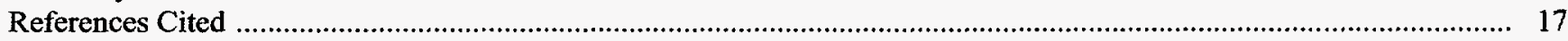

\section{PLATE}

[Plate is in pocket]

1. Hydrogeologic map of the Death Valley region, Nevada and California; and maps showing $A$, hydrogeologic units of the Death Valley region; and $B$, problems with joining map sheets

\section{FIGURES}

1. Map showing location of the Death Valley region, Nevada and California .......................................................

2. Diagram showing observed configurations of ground-water flow in the Great Basin................................................ 4

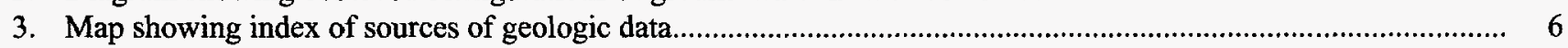

4. Graph showing hydraulic-conductivity distributions estimated for rock types in the Death Valley region............... 15 


\section{TABLES}

1. Correlation of hydrogeologic units with geologic units in the Death Valley region .........................................

2. Correlation of hydrogeologic units with other hydrogeologic units in the Death Valley region ........................ 11

3. Estimated hydraulic conductivity of hydrogeologic units in the Death Valley region ...................................... 16

\section{CONVERSION FACTORS}

\begin{tabular}{rll}
\hline Multiply & By & To obtain \\
\hline meter $(\mathrm{m})$ & Length & foot $(\mathrm{ft})$ \\
kilometer $(\mathrm{km})$ & 0.281 & mile $(\mathrm{mi})$ \\
& Area & \\
square kilometer $\left(\mathrm{km}^{2}\right)$ & 0.3861 & square mile $\left(\mathrm{mi}^{2}\right)$ \\
\hline
\end{tabular}




\title{
A Hydrogeologic Map of the Death Valley Region, Nevada and California, Developed Using GIS Techniques
}

\author{
By Claudia C. Faunt, Frank A. D'Agnese, and A. Keith Turner
}

\section{ABSTRACT}

In support of Yucca Mountain site characterization studies, a hydrogeologic framework was developed, and a hydrogeologic map was constructed for the Death Valley region. The region, covering approximately $100,000 \mathrm{~km}^{2}$ along the Nevada-California border near Las Vegas, is characterized by isolated mountain ranges juxtaposed against broad, alluvium-filled valleys. Geologic conditions are typical of the Basin and Range Province; a variety of sedimentary and igneous intrusive and extrusive rocks have been subjected to both compressional and extensional deformation. The regional ground-water flow system can best be described as a series of connected intermontane basins in which ground-water flow occurs in basin-fill deposits, carbonate rocks, clastic rocks, and volcanic rocks. Previous investigations have developed more site-specific hydrogeologic relationships; however, few have described all the lithologies within the Death Valley regional ground-water flow system.

Information required to characterize the hydrogeologic units in the region was obtained from regional geologic maps and reports. Map data were digitized from regional geologic maps and combined into a composite map using a geographic information system. This map was simplified to show 10 laterally extensive hydrogeologic units with distinct hydrologic properties. The hydraulic conductivity values for the hydrogeologic units range over 15 orders of magnitude due to the variability in burial depth and degree of fracturing.

\section{INTRODUCTION}

Yucca Mountain, located near the western boundary of the Nevada Test Site (NTS) in southern Nevada, has been selected as a potential site for a high-level, nuclear-waste repository. In cooperation with the U.S. Department of Energy (DOE), the U.S. Geological Survey (USGS) is evaluating the site characteristics at Yucca Mountain for its suitability as a repository.

Because of the potential for radionuclides to be transported by ground water from the repository to the accessible environment, studies are being conducted to characterize the Death Valley regional ground-water flow system (Bedinger and others, 1989c) of which Yucca Mountain is a part. Analysis of the regional flow system will help to define the hydrologic conditions at Yucca Mountain and allow for subsequent detailed site-scale hydrologic modeling. In addition, characterizations of the present, past, and future hydrologic regimes at Yucca Mountain and its surrounding areas are required to adequately assess the potential for radionuclides to reach the accessible environment within the first 10,000 years following repository closure. Such characterizations can only be constructed after the current regional ground-water flow system has been analyzed.

The purpose of this study is to develop a conceptual hydrogeologic framework using regional geologic and hydrologic data and to develop a digital hydrogeologic map showing the surface expressions of the framework. This hydrogeologic framework is being developed for ground-water flow modeling. The scope of this study is limited in that the details of the geology were obtained from published regional maps that contain geological details typically shown on 1:250,000 and 1:500,000 scale maps. Synthesis was done using geographic information systems (GIS). 


\section{Purpose and Scope}

This report focuses on the initial phase of regional ground-water flow characterization, the development of a hydrogeologic framework. A hydrogeologic map of the area was produced in digital format to depict the surface expressions of the hydrogeologic system. The report describes the geometry, composition, and physical properties of the materials forming the natural hydrogeologic system, and it serves as an important information source for the development of numerical ground-water flow models. The selection of required numerical modeling parameters is facilitated by using attribute data stored in the data base that accompanies the hydrogeologic map.

\section{Physical Setting}

The Death Valley region, defined in this report by the area between lat $35^{\circ} \mathrm{N}$., long $115^{\circ} \mathrm{W}$., and lat $38^{\circ} \mathrm{N}$., long $118^{\circ} \mathrm{W}$., bounds the Death Valley regional ground-water unit (outlined on fig. 1), as defined by Bedinger and others (1989c). The geographic extent of the study area is shown in figure 1 and includes about $100,000 \mathrm{~km}^{2}$.

The Death Valley region includes Las Vegas, Nevada, and several large prominent valleys, namely Amargosa Valley, Pahrump Valley, and Death Valley (fig. 1). The region also includes several major mountain ranges including the Panamint Range, the Spring Mountains, the Sheep Range, the Amargosa Range, the Kawich Range, the Kingston Range, the Pahranagat Range, the Timpahute Range, and the Last Chance Range (fig. 1). Yucca Mountain, the site of a proposed high-level radioactive-waste repository, is approximately at the geographic center of the Death Valley region on the western boundary of the NTS (fig. 1).

The Death Valley region has a semi-arid to arid climate and is located within the southern Great Basin, a subprovince of the Basin and Range physiographic province. Elevations range from $86 \mathrm{~m}$ below sea level at Death Valley to 3,600 $\mathrm{m}$ above sea level in the Spring Mountains; thus, the region includes a great variety of climatic regimes, and associated ground-water recharge and discharge conditions.

The region is characterized by isolated mountain ranges rising abruptly from broad, alluvium-filled desert basins. The valley bottoms are occupied by local depositional centers usually marked by playa lakes, which act as catchments for surface-water runoff (Grose and Smith, 1989). The Amargosa River, an intermittent stream whose drainage basin covers about
$15,000 \mathrm{~km}^{2}$, discharges into the south end of the Death Valley salt pan (fig. 1), the largest of these playa lakes (Hunt and others, 1966). Most of the basins, however, seldom contain standing water. Some of the playas affected by faulting contain springs where ground water is forced to the surface by juxtaposed lake sediments (Bedinger and others, 1989a; 1989c).

The Death Valley region displays the record of a long and active geologic history, including intermittent marine sedimentation, large-scale compressive deformation, plutonism, volcanism, extensional tectonics, and terrestrial sedimentation (Mifflin, 1988). Consequently, rock types, ages, and deformational structures are highly variable, and in many areas, impressive diversities exist in juxtaposed rock types. As a consequence, subsurface conditions are highly variable and complex. The bedrock geologic conditions beneath alluvial basins are only approximately known in much of the region.

The area contains clastic and crystalline rocks of Precambrian and Cambrian age; Paleozoic clastic and carbonate rocks; Mesozoic clastic and intrusive rocks; varied fluvial, paludal, pond, and playa sedimentary rocks of Pliocene age; volcanic rocks of Tertiary age; and alluvium, colluvium, and eolian dunes of Quaternary age (Waddell, 1982).

\section{Regional Hydrogeology}

Conceptualization of the ground-water flow system requires identification and assessment of system elements, including: (1) definition of hydrogeologic units, (2) distribution of hydrologic properties of the units, (3) distribution and characteristics of geologic structures, and (4) estimates for recharge, discharge, and boundary fluxes.

In an idealized desert-basin flow system, water generally moves downward in recharge areas, then laterally toward discharge areas, and finally upward in discharge areas (Eakin and others, 1976) (fig. 2). Although these general characteristics for flow exist, conditions for idealized flow are rarely met in natural hydrologic environments, particularly in geologically, climatically, and ecologically complex regions. Therefore, to correctly interpret a natural flow system, all deviations from the ideal must be considered.

The conceptual model used is derived from those proposed by Bedinger and others $(1989 \mathrm{a} ; 1989 \mathrm{c})$, Winograd and Thordarson (1975), and Waddell (1982). Conceptually, the ground-water flow system can be thought of as a series of connected intermontane basins, shown on figure 2 , in which localized groundwater flow occurs in basin-fill deposits, clastic rocks, 


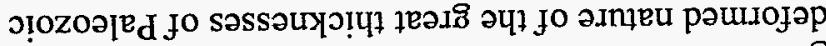

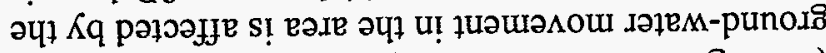

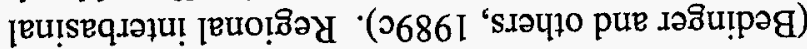

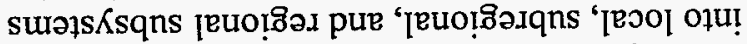

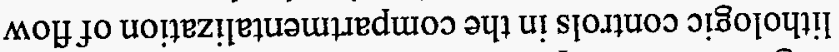

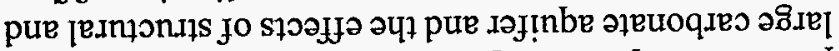

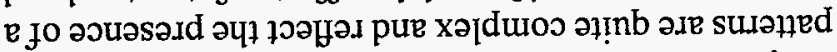

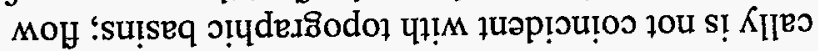

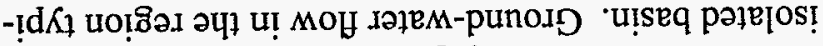

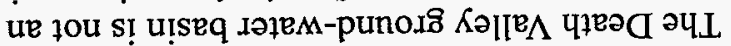

วбมечวәу
-(996 I

's.əųlo pue łunH ‘096I 'uos!qoy pue junH '066I 's.ə

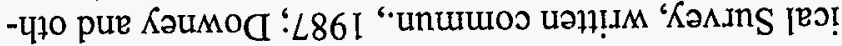

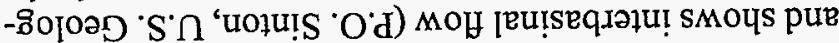

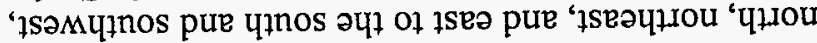

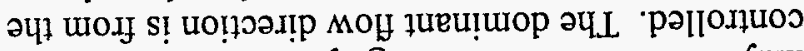

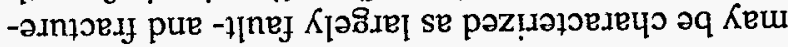

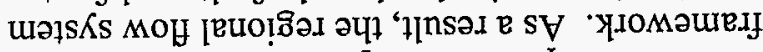

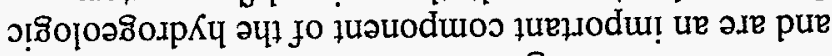

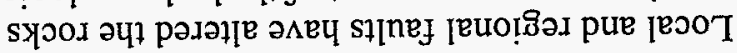

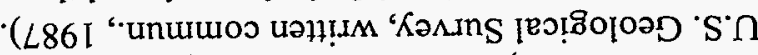

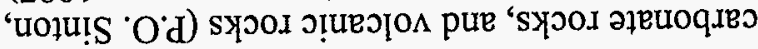

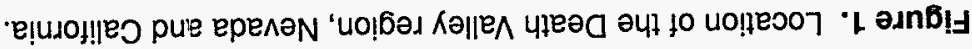

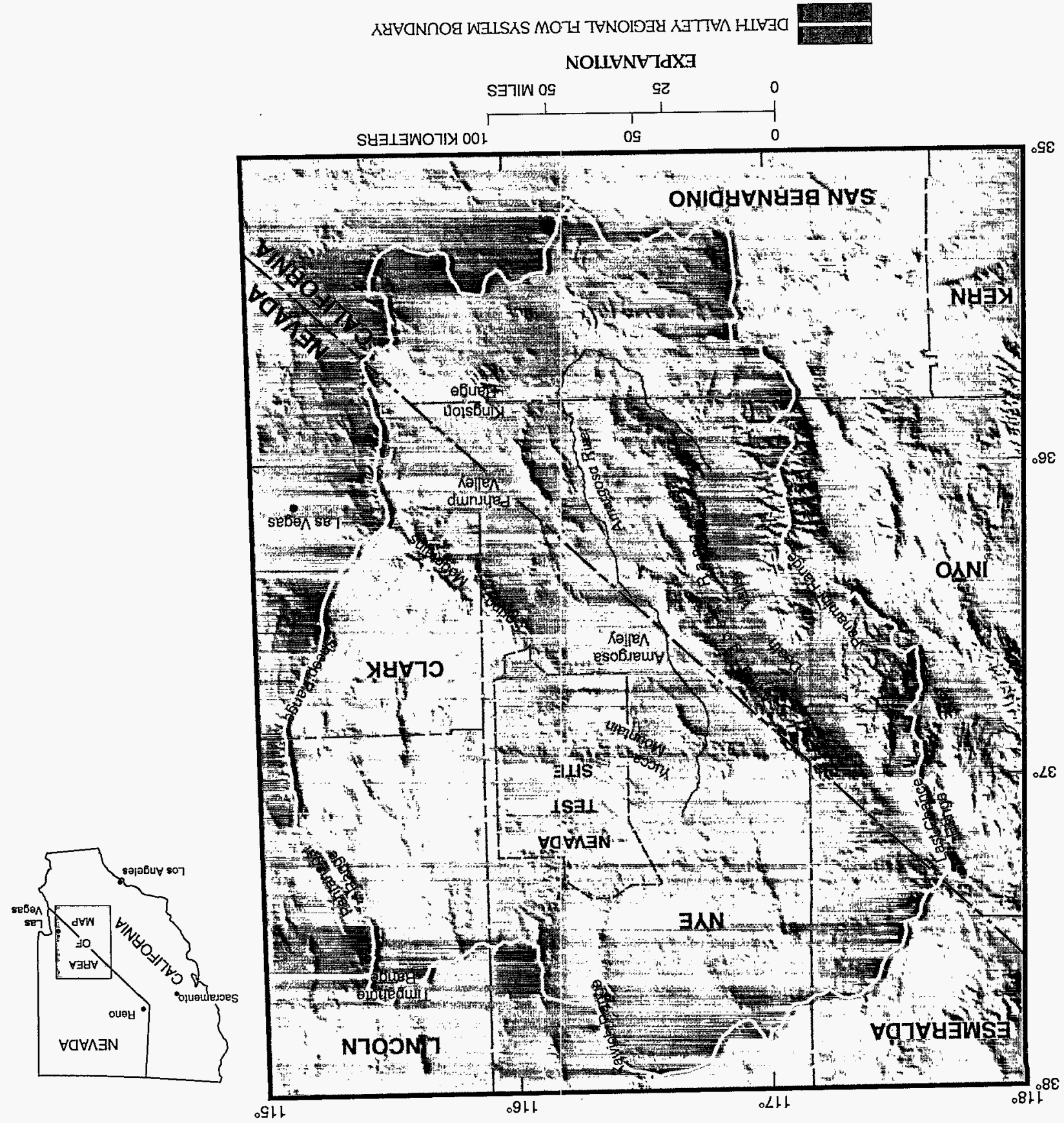




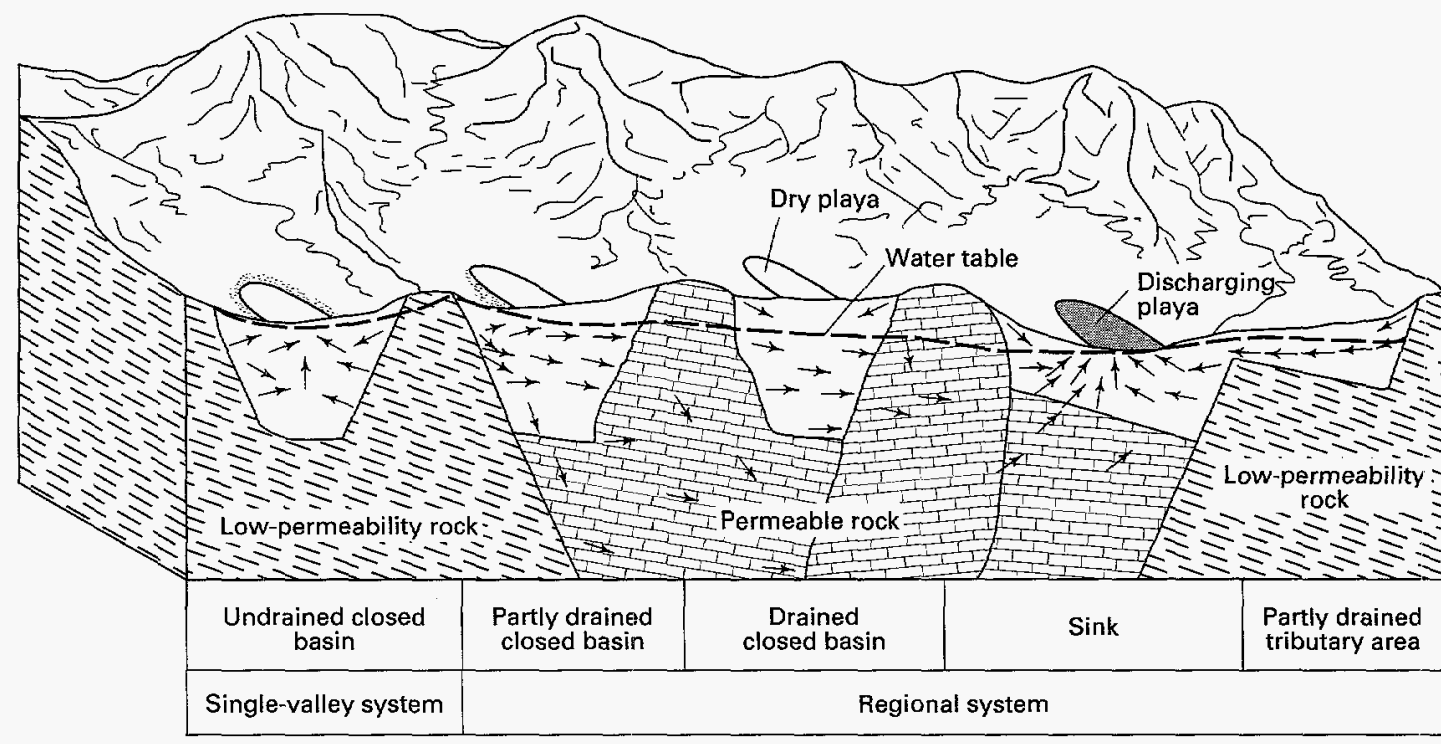

AREAS OF GROUND-WATER EVAPOTRANSPIRATION

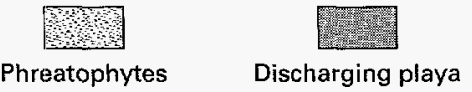

Figure 2. Observed configurations of ground-water flow in the Great Basin (from Eakin and others, 1976).

carbonate and clastic rocks. Major wrench, thrust, and normal faults and folds have been shown to exert marked control on this ground-water movement (Winograd and Thordarson, 1975). Most of the ground water that traverses the boundaries of the basin does so as interbasinal flux.

Aside from interbasinal flux, precipitation in the topographically high areas within the region is a major source of recharge to the ground-water flow system (Prudic and others, 1993). Recharge of this kind dominantly occurs on the mountains that rim the basin.

Smaller quantities of recharge occur through return of irrigation and domestic-use waters, as well as seepage of spring discharge back into the ground-water system (Rice, 1984); however, these lesser components are small compared to regional infiltration and interbasinal flux and may be considered negligible.

Much of the infiltration is from winter and spring storms that produce abundant snow in the mountains, which are capable of sustaining a significant snow pack that melts and infiltrates as recharge. During spring melt, the water seeps slowly into the permeable bedrock or flows off to adjacent drainages where water seeps into alluvium (Prudic and others, 1993). Additional recharge may occur during infrequent, large storms that cause local runoff to stream channels where water infiltrates in concentrated areas along the channel. These recharge events are locally significant, but are less so at regional scales. Both snowmelt and storm-runoff water percolate through bedrock in outcrop areas of extensively fractured carbonate, clastic, and volcanic rocks. In areas where well-developed clayey soils have formed on tuff and argillaceouss rocks, less infiltration occurs.

\section{Discharge}

Natural ground-water discharge is by springs, evaporation in areas where the water table is near the land surface, and through transpiration by plants. The Death Valley salt pan has long been interpreted as the ultimate discharge area for the Death Valley regional ground-water flow system (Eakin and others, 1951, Eakin and others, 1963; Winograd and Thordarson, 1975). Two other major discharge areas are the springs at Ash Meadows and Oasis Valley (Winograd and Thordarson, 1975). Artificially induced discharge occurs in the form of ground-water pumping for agricultural, commercial, and residential uses (Bedinger and others, 1989c). 


\section{DATA SOURCES AND DIGITIZATION PROCEDURES}

The creation of conceptual models and maps of geologically and hydrologically complex regions requires careful data management and quality controls (Turner, 1992). The identification, acquisition, and conversion of suitable data, and proper processing and analysis procedures for these data, are critical for successful characterization and conceptualization. A geographic information system (GIS) was used to manage, store, and analyze the digitized data that were used to develop a hydrogeologic map of the Death Valley region.

\section{Geographic Information Systems}

GISs are used to map and analyze essentially two-dimensional (2D) land surface phenomena. A GIS is not just a computer system for displaying geometric data; rather a GIS is an analytical tool that links spatial data with geographic information (Environmental Systems Research Institute, 1992). As a result, in addition to geometric data, a GIS needs descriptive data and an ability to analyze and compare multiple data sets, both geometrically and analytically. A GIS allows you to identify the spatial relationships between map features.

All GISs have an internal linkage between the data, or attributes, and the geometry. All maps and GISs generalize the geometry to some extent. Maps and GISs convey information by representing features with 2D graphic components: points, lines, and areas. $\mathrm{ARC} / \mathrm{INFO}$ is the GIS used in this study (Environmental Systems Research Institute, 1992).

ARC/INFO is a vector-based GIS that provides digitizing capability, interactive graphics editing, data storage and management (INFO), and graphical manipulation functions as well as sophisticated overlay operators and geographic analysis tools. Each layer or map in ARC/INFO is called a coverage. A coverage consists of topologically linked geographic features and their associated descriptive data. A coverage can contain several feature classes, including points (nodes, vertices, labels, and/or tics), lines (arcs), and/or areas (polygons). ARC/INFO stores the descriptive information for a feature in an INFO data file. This data file is a tabular data file, in which a record (row) stores all the information about one occurrence of a feature (point, arc, or polygon), and an item (column) stores attribute information (Environmental Systems Research Institute, 1992). In $A R C / N F O$, all of the attribute data are linked to a single map and cannot be directly related to other maps without additional analyses. It is a very comprehensive system and almost any type of 2D analysis can be accomplished.

\section{Data Quality Assurance}

Data quality-assurance and control procedures require that: (1) data be safeguarded, secure from any form of data modification, and (2) data must always retain information documenting their origins (Turner, 1992). The original data usually cannot be used directly in building a coherent data base because data collected at different times, by different people, using different methods, will not be consistent. To ensure consistency in the developed data base, three processes were conducted: (1) data validation, (2) data parsing, and (3) data regionalization.

Validation includes the identification of both "errors" and "blunders." Errors include incorrect values occurring in the original data caused by instrument or equipment failures, such as "dropped bits" during electronic data transmission. Blunders include human mistakes resulting from mislabeling, mislocation, or misidentification of data (Turner, 1992).

Data parsing involves the review and conversion of descriptive data to consistent, standard terminology and formats (Turner, 1992). For example, rock unit definitions may change over time, or different geoscientists may use different terms to describe the same unit. Parsing develops a consistency in the data so that they are usable during characterization (Turner, 1992).

Finally, data must be regionalized, or adjusted to represent appropriate levels of detail in order to accomplish the purposes of the map (Turner, 1992). Data should be neither too detailed, nor too generalized, to satisfy the study objectives with maximum efficiency.

The specifics of these processes are discussed in the "Digitizing Procedures" section. D'Agnese and others (1994) give a more detailed description of the processes for the California sheets. Cartier and others (1993) describe similar processes for the Lake Tahoe basin.

\section{Geographic Coordinate System}

In any study involving the integration of disparate data types from numerous sources, care must be taken to make sure the data all have a consistent, standardized coordinate system. Without such a system, the locations of various data items cannot be assessed. Because the development of the hydrogeologic map involved a large geographic region, distortions 
required to represent the curved surface of the Earth on flat maps had to be considered.

Accordingly, all data were projected to the standard Universal Transverse Mercator (UTM) coordinate system, Zone 11, defined by the transverse Mercator projection. The east-west and north-south directions in the UTM are measured in meters. The UTM coordinate system was used because:

1. It has been demonstrated as a useful coordinate system for regional studies at scales of approximately 1:250,000 to $1: 500,000$ (Snyder, 1987);

2. Most of the geology for the area was obtained from maps using UTM;

3. The entire map area fits in a single zone; and

4. The distortions in area and distance are acceptable for project needs.

\section{Data Sources and Data Entry Procedures}

The data acquired for analysis were of three types: existing digital GIS files, published maps, and tabulated data in reports and files. These data were acquired from standardized archives, national data bases, and published reports.

\section{Existing Digital GIS Files}

Existing digital GIS data files were already in a GIS format and have corresponding structured data attribute tables that were directly useful in data analysis and characterization. Data conversion requirements for these data were rather straightforward, and consisted primarily of importation into the desired GIS from an archived format. One such data file was available- - a digital representation of the USGS geologic map of Nevada (Stewart and Carlson, 1978) developed by Turner and Bawiec (1991). This map was acquired as an archived GIS file compatible with ARC/INFO.

\section{Published Map Information}

Published maps represent the second major data type. Published geologic map sheets for the California portion of the Death Valley region were the major nondigital maps used. Parts of four 1:250,000-scale geologic maps cover the California portion of this region. They are part of the geologic report of California, produced by the Division of Mines and Geology, California Department of Natural Resources (Bacon, 1971). These map sheets are:
1. Death Valley sheet (Streitz and Stinson, 1974);

2. Kingman sheet (Jennings, 1961);

3. Mariposa sheet (Strand, 1967); and

4. Trona sheet (Jennings and others, 1962).

The areas covered by these maps are shown in figure 3 .

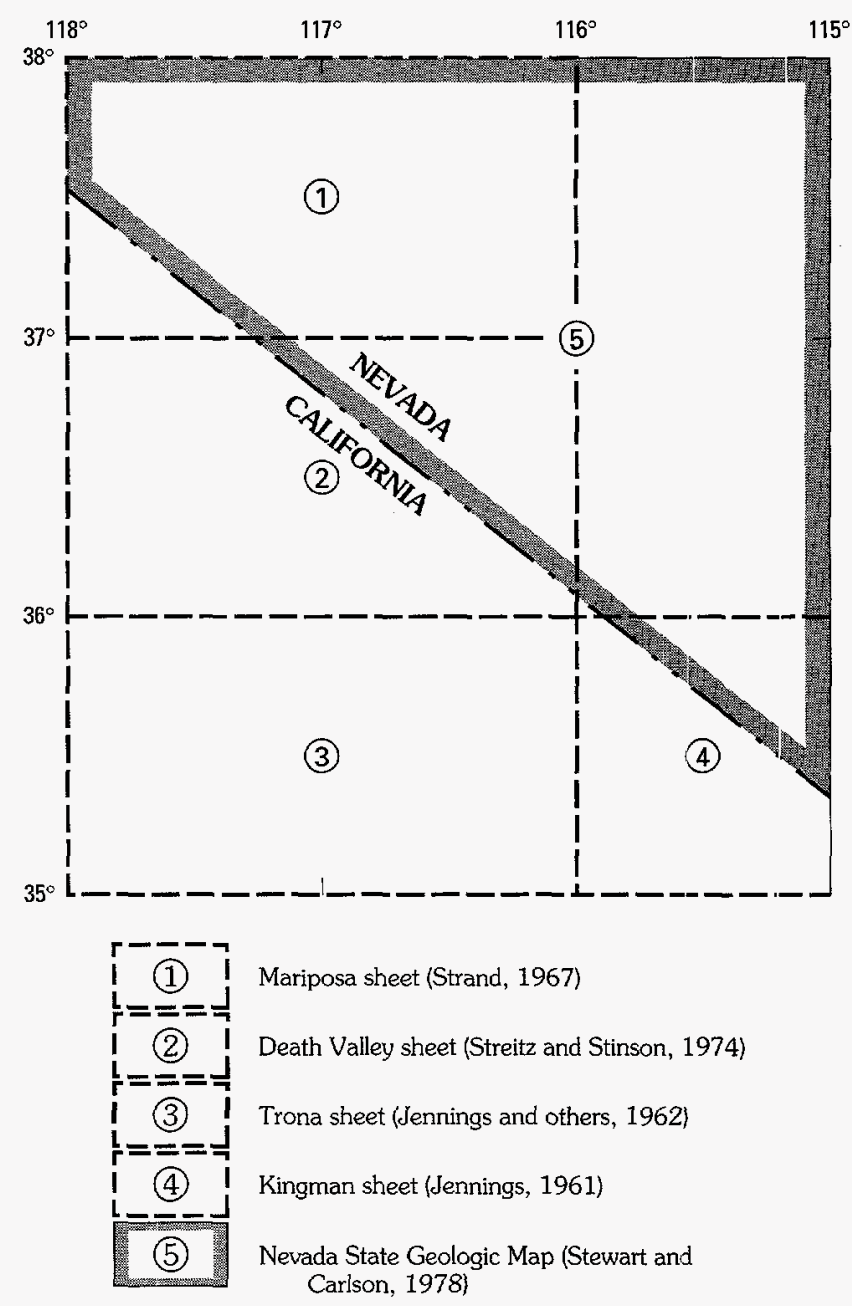

Figure 3. Index of sources of geologic data.

Data digitization, conversion, and preprocessing procedures required to develop a suitable digital map from these published maps were the most timeconsuming procedures involved in the study. These maps were converted to a digital format by a process that involves digitizing/scanning, editing (arc-node aligning), and attribution (Soller and others, 1990). Also, because these maps were not originally generated for this report, they required parsing and regionalization during the conversion process. 


\section{Tabulated Data}

Published or tabulated data include tables of data in reports or in public-access data bases. These data include lithologic names and hydraulic conductivity. Data conversion and preprocessing of published or tabulated data generally involve two forms of data manipulation: data entry of manuscript or published data into computer compatible format, or data reformatting of existing digital files and data bases. In this study, both forms of public-access data were used. Lithologic names were included with the Nevada geologic map in digital format and were reformatted where necessary. The lithologic names for the California geologic maps were entered into the data base. Hydrogeologic units were entered into each data base so that the geologic units could be combined into the proper hydrogeologic units.

\section{Digitizing Procedures}

A procedure for transferring map documents to a digital file format, described in Soller and others (1990), formed the basis for all data digitization. Maps showing geological boundaries and fault traces were scanned by using a raster-to-vector scanner. This process was similar to that described by Bawiec and others (1992) during their development of the digital version of the geologic map of Nevada (Turner and Bawiec, 1991). The processing removed artifacts of the scanning process, transformed the files into a suitable geographic coordinate system, and edited the files to achieve accurate topology. The procedure can be summarized as follows:

1. Geologic unit contacts, faults, and control points were obtained from black-and-white copy.

2. The black-and-white copies of geologic contacts and fault traces were converted to digital format by a raster scanner. The digital files were then converted into a sequence of individual ARC/INFO coverages.

3. The resulting digital map coverages were manually reviewed and corrected for scanning errors such as gaps in lines, stray lines, and incorrect depictions of line intersections. Control points were converted to geographic registration points (ARC/INFO tics). The map coverages were then geographically registered into Zone 11 of the Universal Transverse Mercator coordinate system.
4. For the geologic units coverages, the digital boundaries, represented by lines (or "arcs" in ARC/INFO terminology), were further analyzed to represent polygonal information defining the extent of each geologic map unit. ARC/INFO uses rules of planar enforcement to construct a topologically correct sequence of polygons from such boundary lines. This requires a point to be placed within each polygon representing a geologic unit area, and these points are to be identified or labeled with an alphanumeric code representing that geologic unit. Using ARC/INFO commands, the coverages were analyzed (by the ARC/INFO "clean" and "build" commands) until no errors in topology were identified. For the fault coverages, construction of polygon topology was not required.

5. Tables containing appropriate attributes were constructed within the ARC/INFO system.

6. Each of the coverages was plotted at the original map scale $(1: 250,000)$. The plots were then overlaid on the manuscript sheets and checked for discrepancies. Because the final scale of the map was to be $1: 500,000$, errors less than $250 \mathrm{~m}$ on the ground were not corrected, in accordance with accepted geographic standards (Goodchild, 1993; Nebert, 1989). For the geologic maps, each of the digital geologic map units were plotted in appropriate colors and their agreement with the published maps was checked.

Certain criteria were used to decide which geological information to include and exclude. Only the geologic boundaries, unit identification, and fault data were included in the digitization procedure. Symbols such as anticlines, synclines, strikes, and dips were not included. Dashed contacts and faults were treated as solid lines and were not separately identified in the data base. Fault traces were encoded as simple fault lines and were not attributed with attitude or type. The map control points did not always agree with those contained on the original scale-stable bases. To eliminate any further confusion and to produce a more geographically correct digital file, the resulting map was scaled during digitization to fit the calculated control points. The result is that the digital map will not agree exactly at all locations with the original source materials. 


\section{DIGITAL REPRESENTATIONS OF THE REGIONAL HYDROGEOLOGIC UNITS}

The conceptual model of the regional hydrogeologic systems used is based on the models of Bedinger and others (1989a; 1989c), Winograd and Thordarson (1975), and Waddell (1982). As shown conceptually in figure 2, these authors concluded that the Death Valley ground-water flow system is a series of connected intermontane basins in which ground water flows in basin-fill deposits, carbonate rocks, clastic rocks, and volcanic rocks. Therefore, the characterization of the framework through which the water flows is important to understanding the ground-water flow system.

Since this report is directly concerned with characterization of the regional hydrogeologic system of the Death Valley region, only data specific to the project goals and objectives were gathered for data base incorporation. As a result, detailed large-scale maps were not included in the data acquisition process.

\section{Geologic Information}

The surface bedrock geology provides the basis for the hydrogeologic map. Exposure of the geologic units was taken from regional geologic coverages. Parts of four 1:250,000-scale geologic maps cover the California portion of this region (Jennings, 1961; Jennings and others, 1962; Strand, 1967; and Streitz and Stinson, 1974). Part of the 1:500,000-scale geologic map for the State of Nevada (Stewart and Carlson, 1978) was used for the rest of the area. The locations and extent of these map sheets are shown in figure 3.

\section{California Geologic Maps}

The hydrogeologic map covers a nearly triangular section of southeastern California bounded by the Nevada-California border on the northeast, by long $118^{\circ} \mathrm{W}$ on the west, and by lat $35^{\circ} \mathrm{N}$ on the south (fig. 3). Although the various map sheets in the Geologic Report of California (Bacon, 1971) generally correspond to standard 1:250,000-scale topographic map quadrangles and take their names from these quadrangles, the sheets were extended in some cases (where they border adjacent states) to encompass small parts of adjacent quadrangles. One such extension occurs within the Death Valley region. The Mariposa sheet (Strand, 1967) was extended eastward from the Mariposa topographic map quadrangle to include a small triangular portion of California on the Goldfield, Nevada, topographic map quadrangle.
D'Agnese and others (1994) developed a digital version of this portion of the California geologic maps. The process used is summarized as follows. For the Death Valley (Streitz and others, 1974), Trona (Jennings and others, 1962), and Kingman (Jennings, 1961) sheets, black-and-white map copies plotted on stable-base acetate materials, one showing the geologic unit boundaries and the other the faults (each containing geographic control points), were obtained from the California Division of Mines and Geology. These: copies show the geologic boundaries and faults exactly as they are shown on the original published maps of the Geologic Report of California (Bacon, 1971). Such materials were not available for the Mariposa sheet (Strand, 1967); thus, for the small part of this sheet that was required, the geologic boundaries and the faults were traced from a library copy of the published paper map sheet onto two separate scale-stable masters, along with appropriate control points.

Inevitably, judgments were made in creatirig these digital map files. Small unlabeled units on the source map were combined with nearby units. Whenever possible, this was done after consulting a larger scale, more detailed, geologic map of the area. The geologic unit polygons on these digital map files were attributed to correspond to the geologic units used by the geologic report of California (Bacon, 1971).

Within the region of interest, the geologic materials range in age from Precambrian to Holocene and are composed of metamorphic rocks, carbonate and clastic sedimentary rocks of both marine and continental origin, and plutonic and volcanic igneous rocks. The diverse geology in the California portion of the Death Valley region is defined by 51 geologic units (table 1). These unit names were stored as attributes in the appropriate ARC/INFO tables.

\section{Nevada Geologic Map}

To complete the geologic coverage of the Death Valley region, the USGS digital geologic map of Nevada (Turner and Bawiec, 1991), which corresponds to the published Nevada State geologic map (Stewart and Carlson, 1978), was acquired and imported from its archived file format into ARC/INFO GIS. The data set was an early release version and required some minor editing to correct "errors" and "blunders," such as improperly attributed entities. Once these corrections were made, the map projection was changed to the UTM projection. The area of interest, the portion of Nevada between lat $35^{\circ} \mathrm{N}$., long $115^{\circ} \mathrm{W}$., and lat $38^{\circ} \mathrm{N}$., long $118^{\circ} \mathrm{W}$., was extracted from the state coverage (fig. 3 ). This extracted digital map included 58 geologic units (table 1 ). 
Table 1. Correlation of hydrogeologic units with geologic units in the Death Valley region

[Unit symbol definitions are on map sources: California map sheets (Streitz and Stinson, 1974; Jennings, 1961; Strand, 1967; and Jennings and others, 1962) and Nevada State geologic map (Stewart and Carlson, 1978)]

\begin{tabular}{|c|c|c|}
\hline Hydrogeologic unit & Geologic unit - California map sheets & Geologic unit - Nevada State geologic map \\
\hline Playa deposits of Quaternary age (Qp) & Qst, Q1 & Qp \\
\hline Valley fill of Quaternary-Tertiary age (QTvf) & $\begin{array}{l}\text { Qs, Qal, Qsc, Qf, Qb, Qc, QP, Pmlc, Pc, Mc, Muc, Mmc, } \\
\text { Фc, Epc }\end{array}$ & Qa, Qs, QToa, QTs, Tts, Ts3, Ths, Ts2, TKs, TKsu \\
\hline Lava flows of Quaternary-Tertiary age (QTv) & Qrv, Qpv, Pv, QTv, Ti & QTa, QTb, Tri, Trt, Tr3, Tr2, Tmi \\
\hline Volcanic rocks of Tertiary age (Tv) & $M v . T v, \phi v$ & Tba, Ta2, Tt2, Tbr, Tt3, Ta3, Tb, Tob \\
\hline Volcanic and volcaniclastic rocks of Tertiary age (Tvs) & Qtc, Tc & \\
\hline Granitic rocks of Tertiary-Late Jurassic age ( $\mathrm{TJg}$ ) & gr, bi, gr-m & TJgr, Mzgr, Kgr, Jgr, Rgr, Ti \\
\hline $\begin{array}{l}\text { Sedimentary and metavolcanic rocks of Mesozoic age } \\
\text { (Mvs) }\end{array}$ & $\mathrm{JT} v, \mathrm{mv}, \mathrm{Jml}, \mathrm{T}, \mathrm{ms}, \mathrm{m}, \mathrm{m}$ ls & JTs, JTa, Tch, Tmt, Pc, PPcd, Psc \\
\hline Carbonate rocks of Paleozoic age (P2) & $\mathbb{P v}, \mathbb{P}, \mathrm{Pm}, \mathrm{C}, \mathrm{CP}, \mathrm{CM}, \mathrm{D}, \mathrm{S}, \mathrm{O}, \mathrm{G}$ & $\mathrm{P}, \mathbb{P c}, \mathrm{Mc}, \mathrm{Dc}, \mathrm{St}, \mathrm{Sc}, \mathrm{SOc}, \mathrm{Oc}, \mathrm{OGc}, \mathrm{Gc}, \mathrm{MDs}, \mathrm{Os}, \mathrm{Gt}$ \\
\hline Clastic rocks of Precambrian-Paleozoic age (P1) & G?, Ip 6 & GZq, Gss, Zqs, GZs, Zw \\
\hline Metamorphic rocks of Precambrian age (pGgm) & PG, epG, pGgr & Ygr, Xm \\
\hline
\end{tabular}




\section{Combining Nevada and California Maps}

The California maps were in Universal Transverse Mercator coordinates; the Nevada map was initially in Lambert Conformal Conic coordinates but was converted to Universal Transverse Mercator coordinates. The four California maps were merged first, then the Nevada map was merged with the California coverages. After merging, the edges of the various maps were compared and matched. Boundaries were dropped between areas on adjacent map sheets with identical hydrogeologic units. The resulting combined maps form a hydrogeologic map for the entire Death Valley region (pl. 1).

Numerous limitations are inherent in the creation of these digital map files. They include, but are not limited to:

1. The maps are, at best, accurate only to the scalle of the original digitized map, in this case $1: 250,000$ for California and 1:500,000 for Nevada.

2. The geologic units along the borders of the original California geologic report (Bacon, 1971) map sheets do not match exactly (quadrangle boundary-line faults). This is especially true of the Death Valley sheet (Streitz and Stinson, 1974), which was remapped and reissued later than the other sheets. Even more severe differences are found along the Nevada-California border because the California and Nevada mapping used different sets of geologic units, reflecting different emphases concerning geologic conditions in the two states (state boundary-line faults). Due to the variety of map scales and authors, it was beyond the scope of this study to resolve the differences on the original map sources. The location or classification of geologic features does not match across many of the borders between adjacent maps. Hence, "state boundary-line and quadrangle boundary-line faults" are apparent in several areas when the maps were joined (pl. 1A). When the original geologic units were combined into hydrogeologic units, a number of these problem areas were resolved (pl. $1 B$ ). The remaining discrepancies, inherited from the source maps, remain in the composite coverage. Cartier and others (1993) discuss a similar problem encountered in the Lake Tahoe Basin.

\section{CLASSIFICATION OF HYDROGEOLOGIC UNITS}

The rocks and deposits forming a hydrogeologic system can be classified into hydrogeologic units. A hydrogeologic unit is a unit that has considerable lateral extent and has reasonably distinct hydrologic properties because of its physical (geological and structural) characteristics (Maxey, 1968).

Since the overall study objective was to develop an understanding of the hydrogeology, hydrogeologic units were used for simplification. Although the major geological features were retained, many of the smaller geologic units were grouped into larger entities by generalizing both lithologic and hydrologic properties of the bedrock-geology units. The geologic units found on the regional geologic maps that compose each of these hydrogeologic units are summarized in table 1.

Winograd and Thordarson (1975) divided and combined the various geologic units at the NTS, based on hydrologic properties. Waddell (1982) further described these hydrogeologic units while constructing a numerical ground-water flow model. These authors used hydrogeologic units to describe the aquifers and confining units. These units are similar to, but not exactly the same as, the hydrogeologic units used here. Bedinger and others (1989a; 1989c) expanded Winograd and Thordarson's hydrogeologic units while describing the hydrogeology of the Death Valley region. Grose (1983) and Grose and Smith (1989) subsequently developed cross sections for the Death Valley region based on the hydrogeologic units defined by Bedinger and others $(1989 \mathrm{a} ; 1989 \mathrm{c})$.

Grose (1983) and Grose and Smith (1989) defined and correlated 44 hydrogeologic units. Because their study area was larger than the Death Valley region defined in this report, 12 of these 44 units are not included in this map area. Many of the remaining units have similar hydrologic properties (Bedinger and others, 1989b) or were not considered important on the regional scale. As a result, only 10 hydrogeologic units are defined for the Death Valley region (tables 1 and 2). The abbreviations for the hydrogeologic units were modified from those used by Grose (1983).

Plate 1 shows the surface expressions of the hydrogeologic units. Table 2 summarizes the correlation of the hydrogeologic units with the units described by Winograd and Thordarson (1975), Bedinger and others (1989a), Grose (1983), and Grose and Srnith (1989). 
Table 2. Correlation of hydrogeologic units with other hydrogeologic units in the Death Valley region

[Sources: Waddell (1982) and Bedinger and others (1989a; 1989c)]

\begin{tabular}{|c|c|c|c|}
\hline Hydrogeologic unit & $\begin{array}{l}\text { Hydrogeologic unit } \\
\text { (from Winograd and Thordarson, 1975) }\end{array}$ & $\begin{array}{l}\text { Major hydrogeologic unit } \\
\text { (from Bedinger and others, } 1989 \mathrm{a} \text { ) }\end{array}$ & $\begin{array}{l}\text { Lithostratigraphic unit } \\
\text { (from Grose, 1983; } \\
\text { Grose and Smith, 1989) }\end{array}$ \\
\hline Playa deposits of Quaternary age $(\mathrm{Qp})$ & Valley-fill aquifer & & Qp \\
\hline Valley fill of Quaternary-Tertiary age (QTvf) & Valley-fill aquifer & Basin fill & $\mathrm{Qa}, \mathrm{QTa}, \mathrm{QTs}, \mathrm{Td}, \mathrm{Ts}$ \\
\hline Volcanic rocks of Quaternary-Tertiary age (QTv) & Lava-flow aquifer & Lava flows & Qv, QTb, QTv, Tim, Ti \\
\hline Volcanic rocks of Tertiary age (Tv) & Welded tuff aquifer, bedded tuff aquifer & Ash-flow tuff & Tv, Ttf, Tvr \\
\hline Volcanic and volcaniclastic rocks of Tertiary age (Tvs) & Tuff aquitard, lava-flow aquitard & Undifferentiated volcanic rocks & Tvs \\
\hline Granitic rocks of Tertiary-Late Jurassic age (TJg) & Granitic stock minor aquitard & Crystalline rocks (upper part) & $\mathrm{Tg}, \mathrm{TJg}$ \\
\hline $\begin{array}{l}\text { Sedimentary and metavolcanic rocks of Mesozoic age } \\
\text { (Mvs) }\end{array}$ & & Coarse-grained clastic rocks & RPdc, JR Pd, Mmv, Ms, P3 \\
\hline Carbonate rocks of Paleozoic age (P2) & $\begin{array}{l}\text { Upper carbonate aquifer, } \\
\text { Upper clastic aquitard, and } \\
\text { Lower carbonate aquifer }\end{array}$ & Carbonate rocks & P2, PMd, Od, Gdc \\
\hline $\begin{array}{l}\text { Clastic rocks of Paleozoic-Precambrian age (P1) } \\
\text { Igneous and metamorphic rocks of Precambrian age } \\
\text { (pGgm) }\end{array}$ & Lower clastic aquitard & $\begin{array}{l}\text { Fine-grained clastic rocks } \\
\text { Crystalline rocks (lower part) }\end{array}$ & $\begin{array}{l}\mathrm{Pl}, \mathrm{pCd}, \mathrm{PCc}, \mathrm{p} \in \mathrm{s} \\
\mathrm{p} \in \mathrm{m}, \mathrm{p} \in \mathrm{g}\end{array}$ \\
\hline
\end{tabular}




\section{Playa Deposits of Quaternary Age (Qp)}

The lacustrine confining beds, lake bed sediments of Quaternary age, are a relatively homogeneous deposit composed of mainly clay-sized particles. The unit includes fine-grained playa deposits, lacustrine limestone, and evaporites. Accordingly, the unit can exhibit matrix flow from the permeable unconsolidated deposits and fault and fracture-controlled flow in consolidated deposits (Downey and others, 1990). The lacustrine beds were deposited contemporaneously with the younger alluvial sediments. As a result, the deposits grade into each other. In some of the valleys, the lacustrine confining beds are several hundred meters thick.

\section{Valley Fill of Quaternary-Tertiary Age (QTvf)}

The alluvial sediments of Quaternary-Tertiary age are a heterogenous mixture of volcanic and sedimentary rock detritus ranging from clay to boulder size. The heterogeneous mixture includes units of fine-grained playa and lake beds containing evaporites (of limited areal extent), boulder-cobble-pebble debris flow and fan deposits, and volcanic tuffs. Accordingly, they may exhibit matrix flow in the permeable unconsolidated materials, but fault- and fracture-controlled flow in more indurated materials (Downey and others, 1990). The valley fill (including fluvial deposits) accumulated largely in structural basins. As a result, the valley fill deposits range in thickness from zero at margins of valleys to several hundred meters in valley lowlands. The fill in many basins is greater than $1,300 \mathrm{~m}$ thick and may be as thick as $2,000 \mathrm{~m}$ (Bedinger and others, 1989a). The basin fill forms the major aquifer system in many of the valleys.

These basin fill aquifers constitute a regional system because of the similarities between basins and because they are the most developed source of ground water in the region. Some basins are topographically and hydraulically closed by low-permeability bedrock, while others are part of multibasin flow systems connected by perennial streams or by flow through the basin fill or permeable bedrock (fig. 2). Well yields within the basin fill seem to be related to physiographic setting (Plume and Carlton, 1988). The hydrologic properties of these deposits can differ greatly over short distances, both laterally and vertically, because of abrupt changes in grain size, and the degree of sorting and consolidation.

\section{Volcanic Rocks of Quaternary-Tertiary Age (QTV)}

The volcanic rocks, including lava flows and undifferentiated volcanic rocks of Tertiary and Quaternary age, underlie the valleys and crop out extensively in many of the mountains. The lava flows are primarily basalts, andesites, and rhyolites of Tertiary and Quaternary age. Columnar jointing and platy fractures are common in the flows, which vary from vesicular to dense. Secondary openings are developed along fractures and bedding planes. Individual flows generally are less than $33 \mathrm{~m}$ thick; some are less than $1 \mathrm{~m}$ thick (Bedinger and others, 1989a). Aggregate thicknesses are as much as 1,000 m (Bedinger and others, 1989a).

\section{Volcanic Rocks of Tertiary Age (Tv)}

These volcanic rocks include tuffs and undifferentiated volcanic rocks of Tertiary and Quaternary age. They underlie the valleys and crop out extensively in northern and central portions of the area (pl. 1), including the Yucca Mountain area, where tuffs of Tertiary age are widespread. These units have an aggregate thickness of more than $4,000 \mathrm{~m}$. The composition and structure of these volcanic tablelands, and their position and mode of emplacement, drastically affect regional ground-water flow by altering flow paths, providing numerous avenues of recharge, and altering water-table gradients.

This hydrogeologic unit includes densely welded to nonwelded, bedded, reworked, and air-fall tuffs. Welded ash-flow tuffs characteristically have an interstitial porosity of about 5 percent or less (Bedinger and others, 1989a); thus, the commonly moderate to large hydraulic conductivity of welded ash-flow tuffs is largely a function of secondary openings along joints, bedding planes, and partings within the flows. Where these welded tuffs are not fractured or jointed, they tend to form confining beds; thus, welded tuffs can only transmit significant quantities of water where they are fractured.

In contrast, nonwelded ash-flow tuffs may have a large interstitial porosity, but low hydraulic conductivity and can function as confining beds. Fractures and joints are virtually absent in nonwelded ash-flow tuffs (I.J. Winograd, U.S. Geological Survey, written commun., 1971). Hence, the nonwelded tuffs generally act as confining units. These nonwelded tuffs, however, have limited areal extent. 


\section{Volcanic and Volcaniclastic Rocks of Tertiary Age (Tvs)}

The clastic and tuffaceous aquifers and confining beds are comprised of tuffs and associated sedimentary rocks. They include up to $1,500 \mathrm{~m}$ of a variety of nonwelded to welded ash-flow tuff, ash-fall tuff, tuff breccia, breccia flow deposits, tuffaceous sandstone, siltstone, mudstone, freshwater limestone, and minor amounts of densely welded tuff. Despite the widely differing origins of these rocks, this unit usually has matrices consisting of zeolite or clay minerals (Winograd and Thordarson, 1975), which results in low hydraulic conductivity. Some of the limestone and densely welded tuff may not have zeolitic or clayey matrices, but are believed to have low hydraulic conductivity (Winograd and Thordarson, 1975). These rocks usually separate the more permeable volcanic rocks (Tv) from the Paleozoic carbonate rocks (P2).

\section{Granitic Rocks of Tertiary-Late Jurassic Age (TJg)}

Granitic rocks of Mesozoic and Tertiary age are widespread throughout the southern portion of the region (pl. 1). They outcrop in many mountain ranges and underlie most of the southern portion of the region at depth (Bedinger and others, 1989a). Ground water is thought to occur in these crystalline rocks only where they are fractured. Because the fractures are poorly connected, these rocks are believed to act mostly as confining units.

\section{Sedimentary and Metavolcanic Rocks of Mesozoic Age (Mvs)}

The clastic rocks of Mesozoic age are predominantly continental fluvial, lacustrine, and eolian deposits and clastic and carbonate sedimentary rocks. These rocks form extensive outcrops on the sides of the Spring Mountains where they have been thrusted. The rocks have a variable thickness due to the extensive thrust faulting and are some of the more permeable rocks in the Death Valley region; however, they are not widespread. Some of these rocks are also found in the southwestern portion of the Death Valley region (Bedinger and others, 1989a).

\section{Carbonate Rocks of Paleozoic Age (P2)}

Limestone, dolomite, and calcareous shales of Paleozoic age underlie many valleys and outcrop along the flanks of and throughout some mountains. These carbonate rocks cover an extensive portion of the area around Death Valley, extending to the north and east (pl. 1). They are often interbedded with siltstones and shales and locally interrupted by volcanic rocks in the north. These carbonate rocks, which have an aggregate thickness of about $8,000 \mathrm{~m}$, are probably the most permeable rocks in the area. Where hydraulically connected, they contribute significantly to interbasinal movement of water. This interbasinal movement includes: (1) movement of water within the groundwater basin between topographic basins (fig. 2); and (2) the entrance of ground water from basins to the northeast. Many of the springs in the area are associated with the carbonate rocks. Intergranular flow is not significant in these rocks; the large transmissivity is primarily due to fractures and solution channels (Winograd and Thordarson, 1975). Hydraulic tests of carbonate-rock aquifers throughout eastern and southern Nevada indicate that faults can increase their transmissivity by factors of 25 times or more (Dettinger, 1989).

\section{Clastic Rocks of Paleozoic-Precambrian Age (P1)}

Siltstone, quartzite, shale, sandstone, and some metamorphic rocks of later Precambrian and Paleozoic age form clastic confining units. These rocks vary in aggregate thickness with a maximum thickness of about $3,500 \mathrm{~m}$. These rocks have negligible interstitial ground-water movement but frequently are highly fractured and locally brecciated (Winograd and Thordarson, 1975). At shallow depths, these fractures and breccias can be conduits to flow, converting these clastic rocks into locally important shallow aquifers.

Clastic rocks in the region differ hydrologically from carbonate rocks in two important ways. First, secondary porosity rarely develops along bedding planes in any of the clastic rocks because of the low solubility of their constituents including quartz, mica, and clay minerals. Second, the clastic rocks deform more plastically than the carbonates and, as a result, fractures may become sealed or isolated during deformation (Winograd and Thordarson, 1975). In these rocks, the fractures may be sealed by continued deformation caused by the same process that formed them or by later plastic deformation. Open fractures in interbedded competent rocks may be sealed by plastic deformation of the less competent interbedded strata (Winograd and Thordarson, 1975). 


\section{Igneous and Metamorphic Rocks of Precambrian Age (pGgm)}

Crystalline metamorphic and igneous rocks of Precambrian age are widespread throughout the southern part of the region, cropping out in many mountain ranges and underlying most of the area at depth (Bedinger and others, 1989a). Hydrologically, this unit behaves similarly to the other crystalline rocks in the region (TJg). Ground water is thought to occur only locally in these crystalline bodies where the rock is fractured. Because the fractures are poorly connected, these rocks are believed to act mostly as confining units.

\section{HYDROLOGIC PROPERTIES OF HYDROGEOLOGIC UNITS}

Numerous site-specific, in-situ, and laboratory tests conducted throughout the region are needed to define the hydrologic properties of rocks in the Death Valley region (Bedinger and others, 1989b). Bedinger and others (1989b) conducted a rather extensive search of the literature on the hydrologic properties of rocks in the Death Valley region. Their review indicated that hydrologic properties can range over 15 orders of magnitude in the Death Valley region. They concluded that it was appropriate to evaluate these properties by defining ranges of values for hydraulic conductivity for the major units in the region (Bedinger and others, 1989b). They also discussed the effects of lithology, depth, and degree of fracturing on the hydrologic properties.

Bedinger and others (1989b) compiled values of hydraulic conductivity and porosity for 14 rock types widely represented in the Death Valley region and developed a generalized log-normal plot showing the distributions of the hydraulic conductivity values (fig. 4). Although these hydraulic conductivity plots were developed from generalizations, they represent a good first approximation of the ranges of hydraulic conductivity values in the region. Using the information from figure 4 and the effects of depth and faulting, the hydrologic properties are summarized in table 3 .

Recent hydrogeologic investigations in the Death Valley region have not included any quantitative assessment of the hydraulic role of faults. As a result, little quantitative information is available concerning the influence of regional fault zones on ground-water flow patterns; however, the conceptual model used in this study suggests that regional fault zones may have a considerable influence on the regional ground-water flow system.
Bedinger and others (1989b) believed that the Death Valley regional ground-water flow system is influenced by deep ground-water flow paths. Therefore, they examined the effects of depth on the hydrologic properties of the hydrogeologic framework in the region. They suggested that increased jointing near the surface, caused by stress release by erosional unloading and weathering, may yield larger hydraulic conductivity and porosity values for rocks at shallow depths; however, Bedinger and others (1989b) found that adequate quantitative data were not available in the Death Valley region. Most existing well-yield and specific capacity tests relate to relatively shallow depths in alluvial aquifers (Bedinger and others, 1989b). Constrained by these limitations, Bedinger and others (1989b) searched for and evaluated all available hydrologic property data from a variety of locations. By comparison, with known regional geological conditions, these results were used to estimate hydrologic properties in the Death Valley region. Bedinger and others (1989b) reached the following conclusions:

1. At depths below 150 to $300 \mathrm{~m}$, weathering and fractures due to release of confining pressures by erosional unloading probably are not significant.

2. At increased depths, overburden pressures tend to decrease the apertures of joints or fractures and the size of pores and, therefore, porosity and intrinsic permeability tend to decrease.

3. In some areas, solution-type voids and relict cavernous conditions may withstand overburden pressures in crystalline carbonate rocks, allowing these features to remain open at depths up to 2,000 to $3,000 \mathrm{~m}$.

4. Surface faults and fractures are good indicators of the orientation and position of permeable zones at depths up to $1,000 \mathrm{~m}$.

5. Large, regional, crustal fault zones are good indicators of areas of significant increased hydraulic conductivity at great depths. The regional hydraulic conductivity as a result of fractures is dependent not only on the presence of open fractures, but also on rock type, fracture orientation, and the history of tectonic stress in the region. 
Table 3. Estimated hydraulic conductivity of hydrogeologic units in the Death Valley region

[m, meters per day; >, greater than; <, less than; km, kilometers; sources: Waddell (1982) and Bedinger and others (1989a; 1989b)]

\begin{tabular}{|c|c|c|}
\hline Hydrogeologic unit & Description & $\begin{array}{l}\text { Approximate hydraulic conductivity } \\
\text { (m/day) }\end{array}$ \\
\hline Playa deposits of Quaternary Age (Qp) & Lake bed deposits of silt and clay. & $2 \times 10^{-04}$ (all depths fractured or unfractured) \\
\hline Valley Fill of Quaternary-Tertiary Age (QTvf) & $\begin{array}{l}\text { Alluvial (stream channel and fan gravels), } \\
\text { colluvial, ash fall, and lake deposits. }\end{array}$ & $1 \times 10^{-01}$ (all depths fractured or unfractured) \\
\hline Volcanic rocks of Quaternary-Tertiary Age (QTv) & Rhyolitic, andesitic, and basaltic lava flows. & $\begin{array}{l}\left.4 \times 10^{-04} \text { (unfractured }>150 \mathrm{~m} \text { deep }\right) \\
\left.5 \times 10^{-01} \text { (unfractured }<150 \mathrm{~m} \text { deep; fractured }\right)\end{array}$ \\
\hline Volcanic rocks of Tertiary Age (Tv) & Dominantly rhyolitic ash flow tuffs. & $\begin{array}{l}\left.1 \times 10^{+00} \text { (unfractured }<150 \mathrm{~m} \text { deep; fractured }<3 \mathrm{~km} \text { deep }\right) \\
4 \times 10^{-04} \text { (unfractured }>150 \mathrm{~m} \text { deep; fractured }>3 \mathrm{~km} \text { deep }\end{array}$ \\
\hline Volcanic and volcaniclastic rocks of Tertiary Age (Tvs) & Tuffs and tuffaceous clastic rocks. & $4 \times 10^{-05}$ (all depths fractured or unfractured) \\
\hline Granitic rocks of Tertiary-Late Jurassic Age (TJg) & Granitic rocks. & $\begin{array}{l}3 \times 10^{-07} \text { (fractured }>300 \mathrm{~m} \text { deep) } \\
3 \times 10^{-02} \text { (weathered }<300 \mathrm{~m} \text { deep) } \\
\left.5 \times 10^{-04} \text { (fractured }<300 \mathrm{~m} \text { deep }\right)\end{array}$ \\
\hline Sedimentary and metavolcanic rocks of Mesozoic Age (Mvs) & Dominantly sandstones. & $3 \times 10^{-02}$ (all depths fractured or unfractured) \\
\hline Carbonate rocks of Paleozoic Age (P2) & $\begin{array}{l}\text { Limestones, dolomites, and calcareous } \\
\text { shales. }\end{array}$ & $\begin{array}{l}\left.3 \times 10^{-03} \text { (unfractured }>150 \mathrm{~m} \text { deep }\right) \\
\left.6 \times 10^{-01} \text { (unfractured }<150 \mathrm{~m} \text { deep; fractured }<3 \mathrm{~km} \text { deep }\right)\end{array}$ \\
\hline Clastic rocks of Paleozoic-Precambrian Age (P1) & Conglomerates, argillites and quartzites. & $\begin{array}{l}5 \times 10^{-07} \text { (unfractured) } \\
3 \times 10^{-02} \text { (fractured) }\end{array}$ \\
\hline Igneous and metamorphic rocks of Precambrian Age (pGgm) & $\begin{array}{l}\text { Crystalline rocks (gneisses, schists, and } \\
\text { migmatites). }\end{array}$ & $\begin{array}{l}\left.3 \times 10^{-07} \text { (fractured }>300 \mathrm{~m} \text { deep }\right) \\
3 \times 10^{-02} \text { (weathered }<300 \mathrm{~m} \text { deep) } \\
\left.5 \times 10^{-04} \text { (fractured }<300 \mathrm{~m} \text { deep }\right)\end{array}$ \\
\hline
\end{tabular}




\section{SUMMARY}

A regional hydrogeologic map was constructed for the Death Valley region, Nevada and California. The study area is characterized by isolated mountain ranges juxtaposed against broad, alluvium-filled valleys. Geologic conditions are typical of the Basin and Range province in which a variety of sedimentary and igneous intrusive and extrusive rocks have been subjected to both compressional and extensional deformation. The regional ground-water flow system in the area can best be described as a series of connected intermontane basins, in which ground-water flow occurs in valley fill deposits, carbonate rocks, clastic rocks and volcanic rocks. Previous investigations have developed more site-specific hydrogeologic relationships; however, few have described all the lithologic types within the Death Valley regional ground-water flow system.

ARC/INFO GIS was used to digitize, manage, store and analyze geologic data used to develop the hydrogeologic map. ARC/INFO is a vector-based GIS system that provides digitizing capability, interactive graphics editing, data storage and management, and manipulation functions as well as sophisticated overlay operators and geographic analysis tools. All digital map data entered into this system underwent a series of data quality checks to assure data accuracy.

The data acquired for map development included existing digital GIS files, published maps, and tabulated data in reports and public-access files. All maps requiring digital data entry were digitized following methods developed by Soller and others (1990). Once in digital formats, regional geologic maps were converted to a common coordinate system and combined into one map. The regional geologic map units were then reclassified into 10 hydrogeologic units. Each of these hydrogeologic units has considerable lateral extent and reasonably distinct hydrologic properties. Because the hydrologic properties of these units are also influenced by depth and degree of fracturing, the hydraulic conductivity values of these hydrogeologic units can range over 15 orders of magnitude.

\section{REFERENCES CITED}

Bacon, Forrest, 1971, California's geologic report complete: California Geology, v. 24, no. 6, California Division of Mines and Geology, p. 99-103.

Bawiec, W.J., Traudt, D.K., Ambroziak, R.A., and Arndt, R.E., 1992, The evolution of a digital geologic coverage-From paper to CD-ROM: U.S. Geological Survey Bulletin 2016, chap. E, p. E1-E8.
Bedinger, M.S., Langer, W.H., and Reed, J.E., 1989a, Ground-water hydrology, in Bedinger, M.S., Sargent, K.A., and Langer, W.H., eds., Studies of geology and hydrology in the Basin and Range Province, Southwestern United States, for isolation of high-level radioactive waste-Characterization of the Death Valley region, Nevada and California: U.S. Geological Survey Professional Paper 1370-F, p. F28-F35.

Bedinger, M.S., Langer, W.H., and Reed, J.E., 1989b, Hydraulic properties of rocks in the Basin and Range Province, in Bedinger, M.S., Sargent, K.A., Langer, W.H., Sherman, F.B., Reed, J.E., and Brady, B.T., eds., Studies of geology and hydrology in the Basin and Range Province, Southwestern United States, for isolation of high-level radioactive waste-Basis of characterization and evaluation: U.S. Geological Survey Professional Paper 1370-A, p. A16-A18.

Bedinger, M.S., Sargent, K.A., and Langer, W.H., 1989 c, Studies of geology and hydrology in the Basin and Range Province, Southwestern United States, for isolation of high-level radioactive waste-Characterization of the Death Valley region, Nevada and California: U.S. Geological Survey Professional Paper 1370-F, $49 \mathrm{p}$.

Cartier, K.D., Peltz, L.A., and Smith, J.L., 1993, Development and documentation of spatial data bases for the Lake Tahoe basin, California and Nevada: U.S. Geological Survey Water-Resources Investigations Report 93-4182, $50 \mathrm{p}$.

D’Agnese, F.A., Faunt, C.C., Turner, A.K., 1994, Preliminary digital geologic maps of the Mariposa, Kingman, Trona, and Death Valley sheets, California, U.S. Geological Survey Open-File Report 94-318, 22 p.

Dettinger, M.D., 1989, Distribution of carbonate-rock aquifers in southern Nevada and the potential for their development-Summary of findings: Carson City, Nev., 1985-88, Program for the study and testing of carbonate-rock aquifers in eastern and southern Nevada, Summary Report no. 1, 37 p.

Downey J.S., Kolm, K.E., and Gutentag, E.D., 1990, Selection of geohydrologic boundaries for ground-water flow models: Waste Management ' 90 ', v. 2, Tucson, Ariz., p. 725-734.

Eakin, T.E., Maxey, T.E., Robison, G.B., Fredericks, J.C., and Loeltz, O.B., 1951, Contributions to the hydrology of eastern Nevada: Nevada State Engineers, Water Resources Bulletin, no. 12, p. 171.

Eakin, T.E., Schoff, S.L., and Cohen, P., 1963, Regional hydrology of a part of southern Nevada-A reconnaissance: U.S. Geological Survey Trace Elements Investigations $833,40 \mathrm{p}$. 
Eakin, T.E., Price, Don, and Harrill, J.R., 1976, Summary appraisals of the Nation's ground-water resources-Great Basin region: U.S. Geological Survey Professional Paper 813-G, $37 \mathrm{p}$.

Environmental Systems Research Institute, 1992, Understanding GIS the ARC/INFO method: Redlands, Calif., Environmental Systems Research Institute.

Goodchild, M.F., 1993, Data models and data qualityProblems and prospects, in Goodchild, M.F., Parks, B.O., and Steyaert, L.T., eds., Environmental modeling with GIS: New York, Oxford University Press, p. 94-103.

Grose, T.L., 1983, Thirty-two geologic cross sections, Clark, Esmeralda, Lincoln, Mineral and Nye Counties, Nevada, and adjacent areas in California: Nevada Bureau of Mines and Geology Open-File Report 83-13.

Grose, T.L., and Smith, G.I., 1989, Geology, in Bedinger, M.S., Sargent, K.A., and Langer, W.H., eds., Studies of geology and hydrology in the Basin and Range Province, Southwestern United States, for isolation of highlevel radioactive waste: U.S. Geological Survey Professional Paper 1370-F, p. F5-F19.

Hunt, C.B., and Robinson, T.W., 1960, Possible interbasin circulation of ground water in the southern part of the Great Basin: U.S. Geological Survey Professional Paper 400-B, p. B273-B274.

Hunt, C.B., Robinson, T.W., Bowles, W.A., and Washburn, A.L., 1966, Hydrologic basin, Death Valley, California: U.S. Geological Survey Professional Paper 494-E, $138 \mathrm{p}$.

Jennings, C.W., 1961, Geologic map of California-Kingman sheet: California Division of Mines and Geology, scale $1: 250,000,1$ sheet.

Jennings, C.W., Burnett, J.L., and Troxel, B.W., 1962, Geologic map of California-Trona sheet: California Division of Mines and Geology, scale 1:250,000, 1 sheet.

Maxey, G.B., 1968, Hydrogeology of desert basins: Ground Water, v. 6 , no. 5 , p. $10-22$.

Mifflin, M.D., 1988, Region 5, Great Basin, in Back, William, Rosenshein, J.S., and Seaber, P.R., eds., Hydrogeology: Boulder, Colo., Geological Society of America, The Geology of North America, v. O-2, p. $69-78$.

Nebert, D.D., 1989, Review of edgematching procedures for digital cartographic data used in geographic information systems (GIS): U.S. Geological Survey Open-File Report 89-579, $12 \mathrm{p}$.

Plume, R.W., and Carlton, S.M., 1988, Hydrogeology of the Great Basin region of Nevada, Utah, and adjacent states: U.S. Geological Survey Hydrologic Investigations Atlas 694-A, 1 sheet.
Prudic, D.E., Harrill, J.E., and Burbey, T.J., 1993, Conceptual evaluation of regional ground-water flow in the carbonate-rock province of the Great Basin, Nevada, Utah, and adjacent States: U.S. Geological Survey Open-File Report 93-170, 103 p.

Rice, W.A., 1984, Preliminary two-dimensional regional hydrological model of the Nevada Test Site and vicinity: Richland, Wash., Pacific Northwest Laboratory, SAND83-7466, $44 \mathrm{p}$.

Snyder, J.P., 1987, Map projections - A working manual: U.S. Geological Survey Professional Paper 1395, $383 \mathrm{p}$.

Soller, D.R., Stettner, W.R., Lanfear, K.J., and Aitken, D.S., 1990, A user's manual for a method of map scanning and digital editing for thematic map production and data-base construction: U.S. Geological Survey Circular 1054, $38 \mathrm{p}$.

Stewart, J.H., and Carlson J.E., 1978, Geologic map of Nevada: U.S. Geological Survey Map, scale 1:500,000, 2 sheets.

Strand, R.G., 1967, Geologic map of California-Mariposa sheet: California Division of Mines and Geology, scale 1:250,000, 1 sheet.

Streitz, Robert, and Stinson, M.C., 1974, Geologic map of California - Death Valley sheet: California Division of Mines and Geology, scale 1:250,000, 1 sheet.

Turner, A.K., 1992, Applications of three-dimensional geoscientific mapping and modeling systems to hydrogeological studies, in Turner, A.K., ed., Three-dimensional modeling with geoscientific information systems, NATO ASI Series C: Dordrecht, The Netherlands, Klwer Academic Publishers, Mathematical and Physical Sciences, v. 354, p. 327-364.

Turner, R.M., and Bawiec, W.J., 1991, Digital geologic coverage of Nevada-A digital representation of the 1978 geologic map of Nevada: U.S. Geologic Survey Digital Data Series 2.

Waddell, R.K., 1982, Two-dimensional, steady state model of ground-water flow, Nevada Test Site and vicinity, Nevada-California: U.S. Geological Survey WaterResources Investigations Report 82-4085, $77 \mathrm{p}$.

Winograd, I.J., and Thordarson, William, 1975, Hydrologic and hydrochemical framework, south-central Great Basin, Nevada-California, with special reference to the Nevada Test Site: U.S. Geological Survey Professional Paper 712C, p. Cl-C126. 
NOTICE

Page(s) size did not permit electronic reproduction. Information may be purchased by the general public from the National Technical Information Service, U.S. Department of Commerce, Springfield, VA 22161 (Area Code 703-487-4650). DOE and DOE contractors may purchase information by contacting DOE's Office of Scientific and Technical Information, P.O. Box 62, Oak Ridge, TN 37831, Attn: Information Services (Area Code 423-576-8401). 